\title{
Chemical Composition, Antimicrobial, Cytotoxic and Antiplasmodial Activities of Three Sponges from Buton Islands, Indonesia
}

\author{
Masteria Yunovilsa Putra* and Tri Aryono Hadi \\ Research Center for Oceanography, Indonesian Institute of Sciences \\ Jl. Pasir Putih I, Ancol Timur, Jakarta 14430, Indonesia \\ Email: mast001@lipi.go.id
}

\begin{abstract}
GC-MS analysis of the crude extracts of three different species of Indonesian marine sponges has been carried out for identification of bioactive compounds. The GC-MS analysis from Haliclona (Gellius) sp., Lamellodysidea herbacea, and Spheciospongia inconstans revealed the presence of 23, 21, 19 various compounds, respectively and mainly sterols and fatty acids. All the sponge species has been evaluated for antimicrobial activities, cytotoxicity using brine shrimp lethality bioassay and heme polymerization inhibitory activity assay for antiplasmodial activity. In this study, all the sponge species showed antimicrobial activities against at leastone of the test strains. Among them, the extract of sponge Lamellodysidea herbacea displayed activity against two Gram-positive bacteria (S. aureus and B. subtilis) and the Gram-negative bacteria V. cholerae, with inhibition zones of 10.3, 9.2 and $9.5 \mathrm{~mm}$, respectively. The sponge Haliclona (Gellius) sp., showed significant activity against fungal pathogen C. albicans. The sponge Haliclona (Gellius) sp., displayed the ability to inhibit heme polymerization indicating an anti-Plasmodium function and also showed potent cytotoxic activity against the brine shrimp Artemia sp.
\end{abstract}

Keywords: GC-MS analysis, antimicrobial, sponges, bioactive

\section{Introduction}

In general, natural products play a significant role in the development of drugs. The marine environment is largely unexplored and untapped in comparison with the terrestrial environment. Therefore, research efforts to the discovery of bioactive secondary metabolites have expanded from the land to the ocean. Numerous new secondary metabolites have been isolated, and many were revealed interesting pharmacological activities, most of which were described from marine invertebrates. Marine invertebrates, particular sponges, dominated these studies, due to readily available to collect by snorkeling or scuba diving.

So far, nearly $30 \%$ of all marine natural products or more than 4500 compounds have been isolated from marine sponges (Mehbub et al., 2014). Sponges not only produce the largest number of all marine natural products currently known but also show the most significant chemical diversity of marine natural products including alkaloids, peptides, terpenes and polyketides as most important groups of compounds (Proksch et al., 2003). Anti-cancer, anti-infective, antiinflammatory, neuroprotective, antifouling and several other bioactivities have been disclosed for members of chemical compounds from marine sponges (Mehbub et al., 2014; Blunt et al., 2016).

In term of our ongoing research program aimed at the discovery of marine bioprospecting from Indonesian coast held as one of the richest biodiversity hotspots in the world. We had the opportunity to analyze three different species of sponges. These sponges were collected from Buton Islands (Southeast Sulawesi), and from the crude extract of sponges we have evaluated antimicrobial activities against four human pathogenic bacteria and one pathogenic fungus as well as cytotoxic activity using the brine shrimp lethality bioassay. We also characterized the chemical constituent in the crude extracts by using modern sensitive gas chromatography-mass spectrometry (GC-MS).

\section{Material and Methods}

\section{Sponge materials and extraction}

Three marine sponges were collected by scuba diving from three sites of the Buton Islands and immediately frozen at $-20^{\circ} \mathrm{C}$ until extracted. A voucher record of each specimen was deposited at the Research Center for Oceanography of 
Indonesian Institute of Sciences. The sponge species, locations, and depths of the collection were listed in Table 1. Identification of the sponges was based on their morphological characteristics. Each sponge sample with 200-250 g wet weight was homogenized and extracted with $500 \mathrm{ml} \mathrm{MeOH}$ and $\mathrm{CHCl} 3$ (3:1) at room temperature for $24 \mathrm{~h}$. The sample was filtered, and the residue was repeatedly extracted $(2 \times 500 \mathrm{~mL})$. Then, each sponge extract was evaporated under reduced pressure to obtain crude extracts.

\section{Antibacterial activity}

The screening for antibacterial activity of sponge extracts was carried out using the agar disk diffusion technique as described by Qaralleh et al. (2010), with slight modification. Method Briefly, the sample was prepared with a concentration of 100 $\mu$ g. $\mathrm{mL}^{-1}$ in $\mathrm{MeOH}$. A $20 \mu \mathrm{l}$ sample was dropped on a filter paper disc with $6 \mathrm{~mm}$ diameter. The paper disc was then placed on a Mueller Hinton Agar (Himedia) in a petri dish that had been inoculated with test bacteria $\left(10^{7} \mathrm{CFU} \cdot \mathrm{mL}^{-1}\right)$. Four reference strains of human pathogens were used in this work, including two Gram-negative bacteria (Eschericia coli ATCC 25922, Vibrio cholerae (ATCC 14035), two Grampositive bacteria (Staphylococcus aureus ATCC 25923, Bacillus subtilis ATCC 6633). Inhibition of bacterial growth activity appeared as a clear zone around the paper disc. The inhibition zone was observed after incubation at $30^{\circ} \mathrm{C}$ for $20-24$ hours and then measured using a caliper. As positive controls, ampicillin $10 \mu \mathrm{g} . \mathrm{mL}^{-1}$ will be utilized and methanol as a solvent control. All the assays were performed in triplicate.

\section{Antifungal activity}

The sample was prepared with a

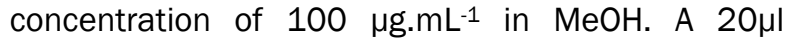
sample was dropped on a filter paper disc with 6 $\mathrm{mm}$ diameter. As a test fungi, Candida albicans ATCC 10231 was used and inoculums containing $10^{4}$ CFU. $\mathrm{mL}^{-1}$ was spread on potato dextrose agar.The anti-fungal activity was measured as a diameter of the inhibitory zones. The inhibition zone was observed after incubation at room temperature for 24-48 h. Nystatin (30 $\mu \mathrm{g} \cdot \mathrm{mL}^{-1}$ ) was used as positive control and methanol as a solvent control.
All the assays were performed in triplicate (Qaralleh et al., 2010)

\section{Cytotoxic activity}

The cytotoxic activity of sponge extracts was evaluated using the brine shrimp lethality bioassay with different concentrations $(50,100,200,400$ $\mathrm{mg} \cdot \mathrm{mL}^{-1}$ ) as described by Ullah et al. (2013), with some modification. Extract and controls were prepared in triplicates. The brine shrimp eggs were placed in hatching tank containing $1 \mathrm{~L}$ of sea water, aerated for $48 \mathrm{~h}$ a room temperature to hatch, under continuous light. After 48 h, 10 brine shrimps were placed in a small container filled with sea water and different concentrations of the extracts. Survivors were calculated after $24 \mathrm{~h}$ of incubation, and the percentage of deaths at each concentration and controls (seawater) were determined.

\section{Heme polymerization inhibitory activity assay}

A total of $100 \mathrm{~mL}$ solution of $1 \mathrm{mM}$ hematin in $0.2 \mathrm{M} \mathrm{NaOH}$ was put into a 96-well microculture plate, and then a $50 \mathrm{~mL}$ assay solution with various concentrations, ranging from 0.3125 to $20 \mathrm{mg} \cdot \mathrm{mL}^{-1}$ (Figure 1.), was added to each well. Glacial acetate acid (50 mL, $\mathrm{pH} 2.6)$ was added to the microculture to initiate a heme polymerization reaction. The microculture was then incubated at $37^{\circ} \mathrm{C}$ for $24 \mathrm{~h}$ to obtain perfect polymerization. After the period of incubation, the microculture was centrifuged and the resulting deposits were washed three times using $200 \mathrm{~mL}$ of dimethyl sulfoxide (DMSO). The solution of $0.1 \mathrm{M} \mathrm{NaOH}(200 \mathrm{~mL})$ was subsequently added to the deposits in each well of microculture. Absorbance values were read at $405 \mathrm{~nm}$ using a microplate reader, Infinite ${ }^{\circledR} 200$ PRO (Tecan Austria $\mathrm{GmbH})$. The value of heme polymerization inhibitory activity was in $\mathrm{IC}_{50}$ (Basilico et al., 1998). Aquadest and chloroquine were used for negative and positive control, respectively. The percentage inhibition of heme polymerization was calculated by the formula:

Inhibition $=\frac{\beta-\text { hematin } 0-\beta-\text { hematin1 }}{\beta-\text { hematin } 0 \times 100 \%}$

Note :

$\beta$-hematino $=$ Concentration of negative control $\beta$-hematin $1=$ Concentration of fraction test

Table 1. Sponge species and collection sites

\begin{tabular}{|c|c|c|c|}
\hline Sponges & Places of collection & Depth (m) & Voucher specimen number \\
\hline Haliclona (Gellius) sp. & $\begin{array}{l}\text { Wa Ara Village, Lakudo District } \\
\left(122^{\circ} 29^{\prime} 17.05^{\prime \prime E ~} 5^{\circ} 36^{\prime} 9.76^{\prime \prime} \mathrm{S}\right)\end{array}$ & $1-5 \mathrm{~m}$ & 1BTN2016 \\
\hline Lamellodysidea herbacea & $\begin{array}{l}\text { Kapoa Village, Kadatua District } \\
\left(122^{\circ} 28^{\prime} 30.25^{\prime \prime E ~} 5^{\circ} 31^{\prime} 1.42^{\prime \prime}\right)\end{array}$ & $1-5 \mathrm{~m}$ & 2BTN2016 \\
\hline Spheciospongia inconstans & $\begin{array}{l}\text { Wabula Village, Wabula District } \\
\left(122^{\circ} 52^{\prime} 2.75^{\prime \prime E} 5^{\circ} 36^{\prime} 55.94 " \mathrm{~S}\right)\end{array}$ & $1-5 \mathrm{~m}$ & 3BTN2016 \\
\hline
\end{tabular}




\section{Zoochemical analysis}

The qualitative analysis of the possible secondary metabolites present in the sponge samples was done following a conventional standardized protocol described by Abioye et al. (2013).

\section{Gas Chromatography Mass Spectroscopy (GC-MS) analysis}

GC-MS analysis was was carried out at the Regional Health Laboratory (Labkesda), DKI Jakarta. The potent open-column samples were injected into Agilent Technologies 7890 GC-Mass with autosampler and 5975 Mass Selective Detector and Chemstation Data System. This instrument was set to electron impact using ionization mode with electron energy $70 \mathrm{eV}$. The column used for analysis was a capillary column HP Ultra $2 \mathrm{~L}$, length $(\mathrm{m})$ $30 \times 0.25(\mathrm{~mm})$ I.D. X $0.25(\mu \mathrm{m})$ film thicknesses

\section{Results and Discussion}

Sponges (phylum Porifera), constitute one of the most primitive of multicellular animals (Metazoa) and play important to the overall ecology of coral reefs. Natural products chemists have been isolating bioactive lead compounds from sponges and commonly described as chemical defense tools to protect against a predator (Burns et al., 2003; Rohde et al., 2015). Sponges have continuously been an important part of Indonesian coral reef communities. Since, the first marine compound, named Laulimalide, isolated from Indonesian sponge Hyattella sp., continuing until now more than 50 publications have reported on the bioactive compounds from Indonesian marine sponges (Putra and Murniasih, 2016).

\section{Antimicrobial activities}

The antimicrobial activities from the marine sponges were evaluated against four human pathogenic bacteria and one pathogenic fungus using the agar disk diffusion assay (Table 2.). According to agar disk diffusion assay of bacteria recorded in this study, all the sponge extracts showed antimicrobial activity against at least one of the test strains.

Against the Gram positive-bacteria, the marine sponge $L$. herbacea extract displayed the highest activity with inhibition zone 10.3 and 9.2 $\mathrm{mm}$ against $S$. aureus and $B$. subtilis, respectively. Furthermore, in vitro growth inhibition of $V$. cholerae was observed in the extract of sponge $L$. herbacea, with inhibition zone $9.5 \mathrm{~mm}$. The antibacterial activity from L. herbacea might be due to the presence of Polybrominated Diphenyl Ethers (PBDEs) that have been reported to have inhibitory potential against the Gram-positive bacteria and the Gram-negative bacteria (Liu et al., 2016). Haliclona (Gellius) sp., showed the highest activity with inhibition zone $9.5 \mathrm{~mm}$ against $B$. subtilis. The crude extract of sponge $S$. inconstans showed relatively high activity against the gram negative-bacteria $E$. coli (Table 2.).

Based on the results from the antifungal assay, Haliclona (Gellius) sp., exhibited to be the most promising antifungal activity. In other studies, the antifungal compound from Haliclona sp. was discovered (Clark et al., 2001; Wattanadilok et al., 2007; El-Amraoui et al., 2013). Antifungal compounds were isolated from Haliclona include a sphingosine derivatives, named haliscosamine from from the Moroccan marine sponge Haliclona viscose (El-Amraoui et al., 2013), nortetillapyrone from Haliclona cymaeformis, collected from the Gulf of Thailand (Wattanadilok et al.,2007), and alkyl amino alcohols, halaminols A-C from sponge Haliclona sp., collected on the Great Barrier Reef (Clark et al., 2001).

\section{Brine shrimp assay}

The results of the brine shrimp bioassay showed that all the sponge extracts showed cytotoxic activity. Mortality of Artemia larvae is shown after a 24 hours exposure to the various concentrations of the sponge extracts. The $\mathrm{LC}_{50}$ values of the crude extract of Haliclona (Gellius) sp., L. herbacea, and S. inconstans were found 92.7, 211.3, $109.4 \mu g . \mathrm{mL}^{-1}$, respectively (Table 3.). The crude extracts resulting in $\mathrm{LC}_{50}$ values less than 100 $\mu \mathrm{g} . \mathrm{mL}^{-1}$ were categorized as having strong cytotoxic and indicated the presence of potent bioactive compounds for further investigation such as anticancer. Artemia nauplii have been shown to present their highest sensitivity to marine invertebrates such as sponges and soft corals (Putra and Murniasih 2016).

\section{Heme polymerization inhibitory activity assay}

The crude extract of sponge Haliclona (Gellius) sp., Spheciospongia inconstans, and Lamellodysidea herbacea were showed inhibitory activity with $\mathrm{IC}_{50}$ values of $11.3,37.8$ and 170.7 $\mu g . \mathrm{mL}^{-1}$, respectively. According to Baelmans et al. (2000), a compound could be considered to have heme polymerization inhibitory activity if it has heme polymerization inhibitor $\mathrm{IC}_{50}$ values smaller than the limit of chloroquine diphosphate, (37.5 mM or 12 mg. $\mathrm{mL}^{-1}$ ). Thus, the extract of Haliclona (Gellius) sp. displayed heme polymerization inhibitory 
Table 2. Antimicrobial activities in the crude extracts of three marine sponges

\begin{tabular}{lccccc}
\hline \multirow{2}{*}{ Sponge species } & \multicolumn{5}{c}{ Zone of inhibition (mm) } \\
\cline { 2 - 6 } & S. aureus & B. subtilis & E. coli & V. cholerae & C. albicans \\
\hline Haliclona (Gellius) sp. & 8.70 & 9.50 & 8.30 & 6.60 & 9.2 \\
L.amellodysidea herbacea & 10.30 & 9.20 & 8.00 & 9.50 & 5.2 \\
Spheciospongia inconstans & 8.10 & 8.30 & 9.45 & 8.90 & 7.8 \\
Ampicillin & 31.60 & 10.5 & 28.70 & 23.7 & - \\
Nystatin & - & - & - & & 20.1 \\
\hline
\end{tabular}

Table 3.Effect of the extract of sponges on brine shrimp survival

\begin{tabular}{llll}
\hline \multicolumn{1}{c}{ Sponges } & LC50 $\left(\mu g \cdot \mathrm{mL}^{-1}\right)$ & Regression equation & $\mathrm{R}^{2}$ \\
\hline Haliclona (Gellius) sp. & 92,7422 & $\mathrm{y}=4,5845 x-4,0189$ & $\mathrm{R}^{2}=0,9961$ \\
Lamellodysidea herbacea & 211,2613 & $\mathrm{y}=3,3719 x-2,8371$ & $\mathrm{R}^{2}=0,8682$ \\
Spheciospongia inconstans & 109,4088 & $\mathrm{y}=3,9699 x-3,0932$ & $\mathrm{R}^{2}=0,9213$ \\
\hline
\end{tabular}

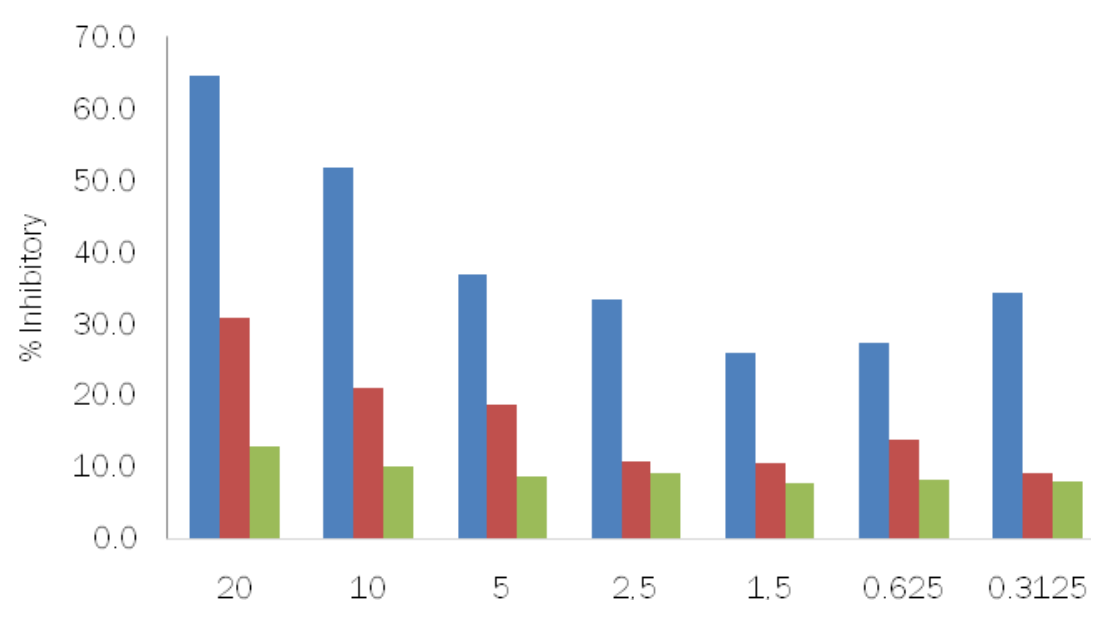

Figure 1. Heme polymerization inhibitory activity assay of sponge extracts

Note. : Haliclona (Gellius)sp, : Speciospongia inconstants, : Lamellodysidea herbacea

activity. Furthermore, the sponge genus of Haliclona are known to contain the antiplasmodial compounds named Haliclona cyclamine A (Mani et al., 2011)

\section{Zoochemical analysis}

This zoochemical analysis of the crude extract of sponges showed that Haliclona (Gellius) sp., L. herbacea, and S. inconstans were positive alkaloids, saponin, and terpenoid. The extracts that tested positive for tannin was $L$. herbacea.

Over the past few years, Gas Chromatography-Mass Spectrometry (GC-MS) has become firmly established as a key technological platform for chemical compound profiling in both plant and marine organisms. Hence the present study we analyzed the crude extract of marine sponges to characterized the bioactive metabolites using GC-MS techniques. The bioactive metabolites with their retention time (RT), molecular formula, molecular weight (MW), concentration (peak area \%) are presented in Tabel 5-7. The results of GC-MS from the sponge extracts contained numerous bioactive compounds belonging to various chemical classes, particularly sterols and fatty acids. Recently, more than 250 polar sterols have been isolated from marine sponges, with three types of the sterol viz. $\Delta^{5}$-sterol, $\Delta^{7}$-sterol and $\Delta^{5,7}$-sterol (Sarma et al., 2005). It has been hypothesized that the sterols in cell membranes of the sponge are related to the presence of unusual fatty acids in their phospholipids.

The marine sponge genus Haliclona (Demospongiae) has been widely studied and well recognized as a rich source of secondary metabolites including steroids, alkaloids, cyclic peptides, terpenoids, and unsaturated fatty acids. Some of these metabolites exhibited interesting biological activities such as the cytotoxic and antimicrobial activity. Previous chemical study of the sponge, Haliclona sp., resulted in unusually fatty acids (Aratake et al., 2009) and many sterols (Elenkov et al., 1999; Cheng et al., 2013). In the Black Sea Haliclona species, the $\Delta^{5}$-sterols 
accounted for $2 \%$ from the total sterol mixture. Furthermore, six unusual a-nor sterols resulted from the Sponge Haliclona oculata collected from Hainan Island, People's Republic of China (Yu et al., 2006). Haliclona (Gellius) sp. metabolites obtained from the crude extract using GC-MS analysis revealed that there were 23 different compounds, mainly constituents of sterols (Table 5). Haliclona (Gellius) sp., from Buton Islands, has a similar sterol profile with those of other species belonging to the same genus (Elenkov et al., 1999; Yu et al., 2006). All these sponges contain $\Delta^{5}$-sterols as a dominant constituent from Haliclona (Gellius) sp.
One of the most widely studied from the sponges of the family Dysideidae is the species of the genus Lamellodysidea (formerly known as Dysidea), L. herbacea. The majority of its secondary metabolites can be divided into three chemical classes: polychlorinated amino acid derivatives, sesquiterpenoids, and polybrominated diphenyl ethers (PBDEs) (Hanif et al., 2007). These secondary metabolites have been found to exhibit avariety biological activities such as antimicrobial, antiinflammatory and cytotoxic activity. The GC-MS analysis of $L$. herbacea extract revealed the presence of various compounds (21 different compounds), such as phenolic compounds, hexadecanoic acid, methyl ester and benzyl alcohol

Table 4. Zoochemical analysis from the crude extract of sponges

\begin{tabular}{cccc}
\hline Zoochemical & Haliclona(Gellius) sp. & Lamellodysidea herbacea & Spheciospongia inconstans \\
\hline Alkaloid & + & + & + \\
Tannin & - & + & - \\
Saponin & + & + & + \\
Terpenoid & + & + & + \\
\hline
\end{tabular}

Table 5. GC-MS spectral analysis of the crude extract of the sponge Haliclona(Gellius) sp.

\begin{tabular}{|c|c|c|c|c|c|}
\hline No. & $\mathrm{RT}(\min )$ & Name of the compound & $\begin{array}{c}\text { Molecular } \\
\text { formula }\end{array}$ & $\begin{array}{c}\text { Molecular } \\
\text { weight }\end{array}$ & $\begin{array}{c}\text { Peak Area } \\
(\%)\end{array}$ \\
\hline 1. & 27.968 & 1,3,5-trimethyl-3,7-diazabicyclo[3.3.1]nonan-9-ol & $\mathrm{C}_{10} \mathrm{H}_{20} \mathrm{~N}_{2} \mathrm{O}$ & 184 & 1.81 \\
\hline 2. & 28.155 & Hexadecanoid acid, methyl ester & $\mathrm{C}_{17} \mathrm{H}_{34} \mathrm{O}_{2}$ & 270 & 1.55 \\
\hline 3. & 28.941 & Piperazine, 2,5-dimethyl-3-(2-methylpropyl) & $\mathrm{C}_{10} \mathrm{H}_{22} \mathrm{~N}_{2}$ & 170 & 2.68 \\
\hline 4. & 29.368 & (9E)-9-octadecenoic acid & $\mathrm{C}_{18} \mathrm{H}_{34} \mathrm{O}_{2}$ & 282 & 1.15 \\
\hline 5 & 29.389 & $\mathrm{~N}$-(N-allylformamide)ethyleneimine & $\mathrm{C}_{6} \mathrm{H}_{10} \mathrm{~N}_{2} \mathrm{O}$ & 126 & 1.60 \\
\hline 6. & 29.506 & Octadecanoic acid, methyl ester & $\mathrm{C}_{19} \mathrm{H}_{38} \mathrm{O}_{2}$ & 298 & 2.23 \\
\hline 8. & 30.037 & n-Propyl decyl ether & $\mathrm{C}_{13} \mathrm{H}_{28} \mathrm{O}$ & 200 & 2.31 \\
\hline 9. & 30.844 & Hexanedioic acid, BIS(2-ethylhexyl) ester & $\mathrm{C}_{22} \mathrm{H}_{42} \mathrm{O}_{4}$ & 370 & 6.97 \\
\hline 10. & 31.389 & Trans-2-methyl-4-n-pentylthiane, S,S-dioxide & $\mathrm{C}_{11} \mathrm{H}_{22} \mathrm{O}_{2} \mathrm{~S}$ & 218 & 4.39 \\
\hline 11. & 31.775 & 8-hexadecenal, 14-methyl-, (Z) & $\mathrm{C}_{17} \mathrm{H}_{32} \mathrm{O}_{2}$ & 252 & 4.63 \\
\hline 12. & 32.140 & Thiophene, 2,5-bis(1,1-dimethylethoxy) & $\mathrm{C}_{12} \mathrm{H}_{20} \mathrm{O}_{2} \mathrm{~S}$ & 228 & 1.09 \\
\hline 13. & 32.402 & 15-hydroxypentadecanoic acid & $\mathrm{C}_{15} \mathrm{H}_{30} \mathrm{O}_{3}$ & 258 & 5.28 \\
\hline 14. & 32.864 & (S)(+)-Z-13-methyl-11-pentadecen-1-ol acetate & $\mathrm{C}_{18} \mathrm{H}_{34} \mathrm{O}_{2}$ & 282 & 3.91 \\
\hline 16. & 33.926 & Cholest-5-en-3-ol (3.beta)-, acetate & $\mathrm{C}_{29} \mathrm{H}_{48} \mathrm{O}_{2}$ & 428 & 2.48 \\
\hline 17. & 35.340 & hexadecadienoic acid, methyl ester & $\mathrm{C}_{17} \mathrm{H}_{30} \mathrm{O}_{2}$ & 266 & 1.97 \\
\hline 18. & 35.615 & 3 $\square$-hydroxy-11-cholenic acid methyl ester & $\mathrm{C}_{25} \mathrm{H}_{40} \mathrm{O}_{3}$ & 388 & 1.77 \\
\hline 19. & 35.822 & (22E)-cholesta-5,22-dien-3-ol & $\mathrm{C}_{27} \mathrm{H}_{44} \mathrm{O}$ & 384 & 7.24 \\
\hline 20. & 36.284 & cholesterol & $\mathrm{C}_{27} \mathrm{H}_{46} \mathrm{O}$ & 386 & 13.91 \\
\hline 21. & 36.850 & ergosta-5,22-dien-3-ol, (3.beta.,2,2E,24S) & $\mathrm{C}_{28} \mathrm{H}_{46} \mathrm{O}$ & 398 & 12.43 \\
\hline 22. & 37.712 & ergosta-5,24(28)-dien-3.beta.-ol & $\mathrm{C}_{28} \mathrm{H}_{46} \mathrm{O}$ & 398 & 4.83 \\
\hline 23. & 39.235 & $\square$-sitosterol & $\mathrm{C}_{29} \mathrm{H}_{50} \mathrm{O}$ & 414 & 8.60 \\
\hline
\end{tabular}<smiles>CC(C)CCC[C@H](C)C1CCC2[C@H]3CC=C4CC(O)CC[C@]4(C)[C@H]3CC[C@@]12C</smiles>

cholesterol ergosta-5,22-dien-3-ol, (3.beta.,2,2E,24S)

Figure 2. Major sterols compounds from of the crude extract the sponge Haliclona(Gellius) sp. 
(Table 6.). Some of the GC-MS peaks remained unidentified, due to of lack of authentic samples and library data of corresponding compounds, particularly for polychlorinated amino acid derivatives, and polybrominated diphenyl ethers (PBDEs).
The GC-MS chromatogram of the crude extract of sponges $S$. inconstans exhibited 19 different compounds (Table 7 ). $\Delta^{5}$-sterols and fatty acids were identified as a dominant constituent from S. inconstans. Stigmasta-5,22-dien-3 $\beta$-ol, acetate, and 26-Nor-5- cholesten-3 $\beta$-ol-25-one were shown

Table 6. GC-MS spectral analysis of the crude extract of the sponge Lamellodysidea herbacea

\begin{tabular}{|c|c|c|c|c|c|}
\hline No. & $\begin{array}{c}\mathrm{RT} \\
(\min )\end{array}$ & Name of the compound & $\begin{array}{l}\text { Molecular } \\
\text { formula }\end{array}$ & $\begin{array}{l}\text { Molecular } \\
\text { weight }\end{array}$ & $\begin{array}{l}\text { Peak Area } \\
(\%)\end{array}$ \\
\hline 1. & 20.963 & $\begin{array}{l}\text { 1H-cyclohepta[B]cyclopenta[C]furan,2,3,3A,4-tetrahydro-3,6,9- } \\
\text { trimethyl }\end{array}$ & $\mathrm{C}_{15} \mathrm{H}_{20} \mathrm{O}$ & 216 & 9.68 \\
\hline 2. & 21.721 & Phenol,3,5-dimethyl-methylcarbamate & $\mathrm{C}_{10} \mathrm{H}_{13} \mathrm{NO}_{2}$ & 179 & 10.17 \\
\hline 3. & 25.086 & Heptadecane & $\mathrm{C}_{17} \mathrm{H}_{36}$ & 240 & 1.55 \\
\hline 4. & 26.045 & 1-methyl-4-(1-methylethylidene)-1-cyclohexene & $\mathrm{C}_{10} \mathrm{H}_{16}$ & 136 & 1.00 \\
\hline 5. & 27.314 & Neophytadiene & $\mathrm{C}_{20} \mathrm{H}_{38}$ & 278 & 2.46 \\
\hline 6. & 27.769 & 6-octen-1-ol, 3,7-dimethyl-, acetate & $\mathrm{C}_{12} \mathrm{H}_{22} \mathrm{O}_{2}$ & 198 & 1.03 \\
\hline 7. & 27.907 & Benzenemethanol, .alpha.,4-dimethyl & $\mathrm{C}_{9} \mathrm{H}_{12} \mathrm{O}$ & 136 & 9.79 \\
\hline 8. & 28.196 & Hexadecanoic acid, methyl ester & $\mathrm{C}_{17} \mathrm{H}_{34} \mathrm{O}_{2}$ & 270 & 6.94 \\
\hline 9. & 28.238 & $\begin{array}{l}\text { 2-cyclononen-1-one, 7-acetyl-3-methyl-9-(1-methylethylidene)-, (Z)- } \\
\text { (.+-.) }\end{array}$ & $\mathrm{C}_{15} \mathrm{H}_{22} \mathrm{O}_{2}$ & 234 & 3.39 \\
\hline 10. & 28.424 & Bicyclo[3.3.0]octan-2-one, 7-ethylidene & $\mathrm{C}_{10} \mathrm{H}_{14} \mathrm{O}$ & 150 & 1.10 \\
\hline 11. & 29.044 & Hexadecanoic acid & $\mathrm{C}_{16} \mathrm{H}_{32} \mathrm{O}_{2}$ & 256 & 4.31 \\
\hline 12. & 29.437 & Cyclohexanone, 5-methyl-2-(1-methylethyl)-,cis & $\mathrm{C}_{10} \mathrm{H}_{18} \mathrm{O}$ & 154 & 1.24 \\
\hline 13. & 30.023 & (9z)-9,17-octadecadienal & $\mathrm{C}_{18} \mathrm{H}_{32} \mathrm{O}$ & 264 & 2.54 \\
\hline 14. & 30.092 & Octadecanoic acid & $\mathrm{C}_{18} \mathrm{H}_{36} \mathrm{O}_{2}$ & 284 & 1.39 \\
\hline 15. & 30.327 & 1,3-dichloro-2-hydroxycarbazole & $\mathrm{C}_{12} \mathrm{H}_{7} \mathrm{Cl}_{2} \mathrm{NO}$ & 252 & 4.45 \\
\hline 16. & 30.809 & 1,4,8-cyclododecatriene & $\mathrm{C}_{12} \mathrm{H}_{18}$ & 162 & 1.16 \\
\hline 17. & 30.885 & Bicyclo[4.3.1]dec-1(9)-ene & $\mathrm{C}_{10} \mathrm{H}_{16}$ & 136 & 2.18 \\
\hline 18. & 31.196 & Pentadecanoic acid & $\mathrm{C}_{15} \mathrm{H}_{30} \mathrm{O}_{2}$ & 242 & 2.69 \\
\hline 19. & 31.451 & Palmitoyl chloride & $\mathrm{C}_{16} \mathrm{H}_{31} \mathrm{ClO}$ & 274 & 5.28 \\
\hline 20. & 32.361 & 4-methyl-thiazol-5-acetaldehyde & $\mathrm{C}_{6} \mathrm{H}_{7} \mathrm{NOS}$ & 141 & 3.28 \\
\hline 21. & 33.092 & Squalene & $\mathrm{C}_{30} \mathrm{H}_{50}$ & 410 & 1.35 \\
\hline
\end{tabular}<smiles>CNC(=O)Oc1cc(C)cc(C)c1</smiles>

Phenol, 3,5-dimethyl-, methylcarbamate<smiles>CC1=CC23CCC(C)C2COC3=C(C)C=C1</smiles>

1H-cyclohepta[B]cyclopenta[C]furan,2,3,3A,4-tetrahydro-3,6,9-trimethyl

Figure 3. Major secondary metabolites from the crude extract of the sponge Lamellodysidea herbacea<smiles>CC[C@H](/C=C/[C@@H](C)[C@H]1CC[C@H]2[C@@H]3CC=C4C[C@@H](OC(C)=O)CC[C@]4(C)[C@H]3CC[C@@]21C)C(C)C</smiles>

Stigmasta-5,22-dien-3-ol, acetate,(3.beta)<smiles>CC(=O)CCC[C@@H](C)[C@H]1CC[C@H]2[C@@H]3CC=C4C[C@@H](O)CC[C@]4(C)[C@H]3CC[C@@]21C</smiles>

26-Nor-5-cholesten-3.beta.-ol-25-one

Figure 4. Major sterol compounds from of the crude extract the sponge Spheciospongia inconstans 
Table 7. GC-MS spectral analysis of the crude extract of the sponge Spheciospongia inconstans

\begin{tabular}{|c|c|c|c|c|c|}
\hline No. & $\mathrm{RT}(\min )$ & Name of the compound & $\begin{array}{c}\text { Molecular } \\
\text { formula }\end{array}$ & $\begin{array}{c}\text { Molecular } \\
\text { weight }\end{array}$ & $\begin{array}{c}\text { Peak Area } \\
(\%)\end{array}$ \\
\hline 1. & 27.898 & 1-Hydroxysulfonyl-3,4,4-trimethyl-2-azetidinone & $\mathrm{C}_{6} \mathrm{H}_{11} \mathrm{NO}_{4} \mathrm{~S}$ & 193 & 1.23 \\
\hline 2. & 29.989 & oleic acid & $\mathrm{C}_{18} \mathrm{H}_{34} \mathrm{O}_{2}$ & 282 & 5.11 \\
\hline 3. & 30.237 & 6-methyl-2-tridecanone & $\mathrm{C}_{14} \mathrm{H}_{28} \mathrm{O}$ & 212 & 3.08 \\
\hline 4. & 30.306 & piperazine, 2,5-dimethyl-, cis & $\mathrm{C}_{6} \mathrm{H}_{14} \mathrm{~N}_{2}$ & 114 & 1.08 \\
\hline 5. & 30.726 & methyl(1Z)-N-[(Z)-1-methylethyl]-3-phenylpropanimidoate & $\mathrm{C}_{13} \mathrm{H}_{19} \mathrm{NO}$ & 205 & 2.47 \\
\hline 6. & 30.837 & 1-(hexadecyloxy)ethylene & $\mathrm{C}_{18} \mathrm{H}_{36} \mathrm{O}$ & 268 & 3.46 \\
\hline 7. & 31.775 & Batilol & $\mathrm{C}_{21} \mathrm{H}_{44} \mathrm{O}_{3}$ & 344 & 3.51 \\
\hline 8. & 33.505 & Spiro[4.5]decane, 6-methylene & $\mathrm{C}_{11} \mathrm{H}_{18}$ & 150 & 4.96 \\
\hline 9. & 33.636 & (22E)-ergost-22-en-3-ol & $\mathrm{C}_{28} \mathrm{H}_{48} \mathrm{O}$ & 400 & 1.86 \\
\hline 10. & 33.781 & Cholesta-4, 6-dien-3-ol, benzoate, (3.beta.) & $\mathrm{C}_{34} \mathrm{H}_{48} \mathrm{O}_{2}$ & 488 & 4.91 \\
\hline 11. & 33.926 & Stigmastan-3.5-diene & $\mathrm{C}_{29} \mathrm{H}_{48}$ & 396 & 4.91 \\
\hline 12. & 34.291 & Cholest-5-en-3-yl palmitate & $\mathrm{C}_{43} \mathrm{H}_{76} \mathrm{O}_{2}$ & 625 & 3.42 \\
\hline 13. & 35.567 & Stigmastan-6,22-dien,3,5-dedihydro & $\mathrm{C}_{29} \mathrm{H}_{46}$ & 394 & 7.99 \\
\hline 14. & 35.801 & Stigmasta-5,22-dien-3-ol, acetate,(3.beta) & $\mathrm{C}_{31} \mathrm{H}_{50} \mathrm{O}_{2}$ & 454 & 10.45 \\
\hline 15. & 36.270 & 26-Nor-5-cholesten-3.beta.-ol-25-one & $\mathrm{C}_{26} \mathrm{H}_{42} \mathrm{O}_{2}$ & 386 & 27.65 \\
\hline 16. & 36.822 & 5, 6-dihydro-3a-ergosterol & $\mathrm{C}_{28} \mathrm{H}_{46} \mathrm{O}$ & 398 & 5.86 \\
\hline 17. & 37.532 & Cholesta-4, 6-dien-3-one & $\mathrm{C}_{27} \mathrm{H}_{42} \mathrm{O}$ & 382 & 4.87 \\
\hline 18. & 39.159 & beta.-sitosterol & $\mathrm{C}_{29} \mathrm{H}_{50} \mathrm{O}$ & 414 & 1.60 \\
\hline 19. & 39.201 & Stigmasta-5-en-3-ol & $\mathrm{C}_{29} \mathrm{H}_{50} \mathrm{O}$ & 414 & 1.35 \\
\hline
\end{tabular}

to be the main sterols in the sponge extract. The result is a previous investigation from the Caribbean sponge Spechiospongia vesparia found a phospholipid named (6Z)-2-methoxy-6-hexadecenoic acid and three group of sterols, $\Delta^{5}, \Delta^{0}$ and $\Delta^{5,7}$ (Roberto et al., 1998).

\section{Conclusion}

Marine sponges collected from Buton Islands have shown to possess various bioactive compounds and also have potential biological activities such as antimicrobial, cytotoxic and antiplasmodial activities. In our studies, the most interesting species are L. herbacea and Haliclona (Gellius) sp. These organisms will be subjected to detailed research for the isolation of biologically active compounds along with the search for new compounds.

\section{Acknowledgements}

This work was supported by a research grant from the Coral Reef Rehabilitation and Management Program-Coral Triangle Initiative (COREMAP CTI-LIPI 2016 No. 10876401/ADB LOAN No. 3094-INO), Indonesian Institute of Sciences awarded to Tri Aryono Hadi and Masteria Yunovilsa Putra

\section{References}

Abioye, E.O., Akinpelu, D.A., Aiyegoro, O.A., Adegboye, M.F., Oni, M.O. \& Okoh, A.I. 2013. Preliminary phytochemical screening and antibacterial properties of crude stem bark extracts and fractions of Parkia biglobosa (Jacq.). Molecules, 18(7):8485-8499. doi: 10.3390/molecules180 78485 .

Aratake, S., Trianto, A., Hanif, N., Voogd, N.J.D. \& Tanaka, J. 2009. A new polyunsaturated brominated fatty acid from a Haliclona sponge. Mar. Drugs. 7(4):523-527. doi: 10.3390/md 7040523

Basilico, N., Pagani, E., Monti, D., Olliaro, P., \& Taramelli, D. 1998. A microtitre-based method for measuring the haem polymerization inhibitory activity (HPIA) of antimalarial drugs. J. Antimicrob. Chemother. 42(1):55-60.

Baelmans, R., Deharo, E., Muñoz, V.,Sauvain, M. \& Ginsburg, H. 2000. Experimental conditions for testing the inhibitory activity of chloroquine on the formation of beta-hematin. Exp. Parasitol., 96(4):243-8. doi: 10.1006/expr.2000.4558

Blunt, J.W., Copp, B.R., Keyzers, R.A.,Munro, M.H.G. \& Prinsep, M.R. 2016.Marine natural products. Nat. Prod. Rep., 33(3):382-431. doi: 10.1039/ c5np00156k.

Burns, E., Ifrach, I., Carmeli, S., Pawlik J.R.\& Ilan M. 2003. Comparison of anti-predatory defences of Red Sea and Caribbean sponges. I. Chemical defence. Mar. Ecol. Prog. Ser. 252:105-114. doi: 10.3354/meps252105

Cheng, Z.B., Xiao, H., Fan, C.Q., Lu, Y.N., Zhang, G.\& Yin, S. 2013. Bioactive polyhydroxylated sterols from the marine sponge Haliclona crassiloba. 
Steroids, 78(14):1353-8. doi: 10.1016/j. steroids.2013.10.004

Clark, R.J., Garson, M.J.\&Hooper, J.N.A. 2001. Antifungal alkyl amino alcohols from the tropical marine sponge Haliclonan. sp.J. Nat. Prod., 64(12):1568-1571. doi: 10.1021/np01 $0246 \mathrm{x}$

Elenkov, I., Popov, S. \& Andreev, S. 1999. Sterols from two Black Sea sponges (Haliclona Sp.). Comp. Biochem. Physiol. B Biochem. Mol. Biol., 123(4):357-360. doi: 10.1016/S0305-0491 (99)00079-6

El-Amraoui, B., Biard, J.F. \& Fassouane, A. 2013. Haliscosamine: a new antifungal sphingosine derivative from the Moroccan marine sponge Haliclona viscosa. Springer Plus. 2:252. doi: 10.1186/2193-1801-2-252

Hanif, N.,Tanaka, J., Setiawan, A., Trianto, A., Voogd, N.J.D., Murni, A.,Tanaka, C. \& Higa, T. 2007. Polybrominated diphenyl ethers from the Indonesian Sponge Lamellodysidea herbacea. J. Nat. Prod. 70(3):432-435. doi: 10.1021/np 0605081

Liu, H., Lohith, K., Rosario, M., Pulliam, T.H., O'connor, R.D., Bell, L.J. \& Bewley, C.A. 2016. Polybrominated diphenyl ethers: Structure determination and trends in Antibacterial activity. J. Nat. Prod. 79(7):1872-1876. doi: 10.1021/acs.jnatprod.6b00229

Mani, L., Petek, S, Valentin, A., Chevalley, S., Folcher, E., Aalbersberg, W. \& Debitus, C. 2011. The in vivo anti-plasmodial activity of haliclona cyclamine $A$, an alkaloid from the marine sponge, Haliclona sp. Nat. Prod. Res. 25(20): 1923-1930.

Mehbub, M.F., Lei, J., Franco, C. \& Zhang, W. 2014. Marine sponge derived natural products between 2001 and 2010: trends and opportunities for discovery of bioactives. Mar. Drugs. 12(8):4539-77. doi: 10.3390/md120 84539.

Roberto, A-E., Arreguín, B., Hernández-Santoyo, A. \& Rodriguez-Romero A. 1998. Sterol composition and biosynthesis in the sponge Spheciospongia vesparia. J. Chem.Technol. Biotechnol. 72(3):245-248. doi: 10.1002/(SICI)1097-4660
(199807)72:3<245::AID-JCTB904>3.0.CO;2-M

Rohde, S., Nietzer, S. \& Schupp P.J. 2015. Prevalence and mechanisms of dynamic chemical defences in tropical sponges. Plos One, 10(7):e0132236. doi: 10.1371/journal. pone.0132236

Sarma, N.S., Krishna, M.S.R. \& Rao, S.R. 2005. Sterol ring system oxidation pattern in marine sponges. Mar. Drugs. 3(3):84-111. doi:10. 3390/md303084

Ullah, M.O., Haque, M., Urmi, K.F., Zulfiker, A.H.M., Anita, E.S. Begum, M. \& Hamid K. 2013. Antibacterial activity and brine shrimp lethality bioassay of methanolic extracts of fourteen different edible vegetables from Bangladesh. Asian Pac. J. Trop. Biomed. 3(1):1-7. doi: 10.1016/S2221-1691(13)60015-5

Proksch, P., Ebel, R., Edrada, R.A.,Wray, V., Steube, K. 2003. Bioactive Natural Products from Marine Invertebrates and Associated Fungi. In: Müller, W. E. G. (Ed). Marine Molecular Biotechnology Springer-Verlag, Berlin. p. 117138. doi: 10.1007/978-3-642-55519-0_5

Putra, M.Y. \& Murniasih, T. 2016. Distribution and diversity of marine natural products from Indonesian marine organisms. J. Coast. Life Med. 4(2):104-107. doi: 10.12980/jclm.4. 2016j5-236

Qaralleh, H., Idid, S., Saad, S., Susanti, D., Taher, M. \& Khleifat, K. 2010. Antifungal and Antibacterial Activities of Four Malaysian Sponge Species (Petrosiidae). J. Mycol. Med. 20(4):315-320. doi: 10.1016/j.mycmed.201 0.10 .002

Wattanadilok, R., Sawangwong, P., Rodrigues, C., Cidade, H., Pinto, M., Pinto, E., Silva, A. \& Kijjoa, A. 2007. Antifungal Activity Evaluation of the Constituents of Haliclona baeri andHaliclona cymaeformis, Collected from the Gulf of Thailand. Mar. Drugs. 5(2): 40-51. doi: 10.3390/md502040

Yu, S., Deng, Z., Proksch, P. \& Lin, W. 2006. Oculatol, Oculatolide, and A-nor Sterols from the Sponge Haliclona oculata. J. Nat. Prod. 69(9):1330-1334. doi: 10.1021/np0600494 